\title{
Oil Price Uncertainty and Savings in South Africa
}

\author{
Diksha Dave and Goodness C. Aye* \\ Department of Economics \\ University of Pretoria \\ South Africa
}

\begin{abstract}
Oil prices have become increasingly important to determine indicators such as inflation; this in turn affects savings and investments. This paper investigates the impact of the volatility of oil prices on savings in South Africa using quarterly data covering the period 1960 to 2014 . The study used the GARCH-in-mean VAR model. This model also provides a way of examining the effect of a negative and positive shock in oil prices on savings. The outcome of this study proves that oil price uncertainty which is measured as the conditional standard deviation of a one-step-ahead forecast error of the change in oil price affects South Africa's savings in a negative way. The responses of savings to a positive and negative oil price shocks is symmetric in both direction and magnitude.
\end{abstract}

\section{Introduction}

The literature has suggested that if a country has sustained high levels of savings, it will lead to sustained economic growth. For instance Al-Khouri and Dhade (2014) investigates the links between oil price changes, national savings, legal and institutional development, and economic growth. The results showed that there was a non-linear and concave relationship between economic growth and saving rates. This implies that if economic growth is low, an increase in savings would significantly increase economic growth. Once the country shows a

\footnotetext{
*Corresponding Author’s Email: goodness.aye@gmail.com
} 
significant increase in growth, an increase in savings would only create little economic growth. They have assumed the reason for this was due to the absence of absorption capacity to keep investments low but savings high.

The above finding is also consistent with theory from models such as the Solow (1956) model. Therefore, savings and investments are necessary for growth in a country. South Africa in particular, has had a problem in terms of not having enough savings for growth, not forgetting the low business confidence due to political and labour issues recently. Of course savings is not the only component that will help, but it would have a significant contribution towards economic growth and mostly investments. The purchasing power of both individuals and businesses depends on the amount of disposable income that they have. Consumers for example, have to pay more for fuel, regardless of which form of transport they use. Businesses costs increase with rises in oil prices, leaving less money to invest with. Household savings (in current terms) had been positive until the year 2006 and had seen negative values since then. The latest value reported by the South African Reserve Bank (SARB) was R3102 million in the second quarter of 2014 (Trading Economics, 2014).

While oil prices have been increasing over the past 40 years, it has become more volatile since the early 2000's. Prices declined sharply due to the global financial crisis in 2009 . The price however, recovered and was back to the prices before the crisis, in the year 2011 (U.S. Energy Information Administration, 2014). Theoretically, oil prices affect the economy through their effects on pricing and production costs or due to their effects on aggregate demand (i.e. via inflation and monetary policy channels) and aggregate supply (i.e. via output) (Degiannakis et. al., 2013). There is also the income-transfer channel that emphasizes the transfer of income from oil importing countries to oil exporting countries associated with 
increases in oil prices (Elder and Serletis, 2010). Increases in oil demand without offsetting increases in supply lead to higher oil prices. Higher oil prices act like an inflation tax on consumers and producers by reducing the amount of disposable income consumers have left to spend on other goods and services and raising the costs of non-oil producing companies and, in the absence of fully passing these costs on to consumers, reducing profits and dividends (Basher and Sadorsky, 2006).

The negative impact of oil price on the economy is also supported by Lescaroux and Mignon (2008) who noted that an oil price increase may have a negative impact on consumption, investment and employment. They noted that the negative effect on consumption arising from oil price increases that subsequently decreased households' purchasing power can be mitigated if consumers expect the rise in oil prices to be transitory. In this case, they will attempt to smooth their consumption by saving less or borrowing more, pushing real interest rates upward. In addition to global demand and supply conditions, oil prices also respond to geopolitics, institutional arrangements (OPEC), and the dynamics of the futures market (Sadorsky, 2004). Unanticipated changes in any of these four factors can create volatility, and hence risk, in oil futures prices. Oil price volatility increases risk and uncertainty which reduces output, wealth, durable consumption, savings/investment, employment and overall economic growth (Sadorsky, 1999; Papapetrou, 2001; Basher and Sadorsky, 2006; Nkomo, 2006; Elder and Serletis, 2010).

Empirically, a number of studies have investigated the impact of oil price uncertainty on economic activities. For example Elder and Serletis (2010) focused on how oil prices affect economic activities. Their findings indicate a negative effect on investment, consumption of durables and aggregate output. Investment and savings are highly correlated and therefore 
one would expect a similar result of oil price volatility on savings. This in turn affects the levels of overall demand. Aye et al. (2014) examined the volatility of oil prices and its effects on the manufacturing sector in South Africa. This is the first paper to account for in particular, the volatility of oil prices in South Africa. The conclusion was that oil price uncertainty negatively affected manufacturing production in South Africa which has implications for employment in the manufacturing sector and overall growth. More so, the study finds an asymmetric response of manufacturing production to positive and negative oil price shocks.

Olson et al. (2014) examined the relationship between the energy and equity markets by estimating volatility impulse response functions from a multivariate BEKK model of the Goldman Sach's Energy Index and the US S\&P 500. Using weekly data covering from January 1st 1985 to April 24th 2013, they showed that low S\&P 500 returns cause substantial increases in the volatility of the energy index; however, they found only a weak response from S\&P 500 volatility to energy price shocks. Lin et al. (2014) examined the dynamic volatility and volatility transmission between oil and Ghanaian stock market returns in a multivariate setting using the VAR-GARCH, VAR-AGARCH and DCC-GARCH frameworks. Their findings point to the existence of positive and significant volatility spillover and interdependence between oil and the two stock market returns. Omojolaibi and Egwaikhide (2014) used quarterly data between 1990:q1 and 2010:q4 and a panel vector autoregressive technique to examine the impact of oil price volatility on economic performance of five oil-exporting countries in Africa (Algeria, Angola, Egypt, Libya and Nigeria). Evidence from the impulse response function shows that gross investment respond more effectively to oil price volatility while fiscal deficit, real GDP and money supply responses are less effective. 
The study by Lescaroux and Mignon (2008) is worth mentioning though it considered oil price levels and not the volatility. However, it considered the relationship between oil prices and a wide coverage of macroeconomic and financial variables (GDP, CPI, household consumption, unemployment rate and share prices) for a large set of countries. On one hand, their short-term results show that when Granger-causality exists, it generally runs from oil prices to the other variables. For instance, oil prices were found to have Granger-cause share prices negatively. These results were also confirmed by their calculation of cyclical correlations especially between oil prices and share prices where oil prices were found to lead counter cyclically share prices for almost every country. On the other hand, the long-term analysis showed that oil prices have long-run relationship with GDP, unemployment rate and share prices.

As far as oil price uncertainty and savings in concerned, there appears to be little or no empirical research. The only known study is Baskaya et al. (2013) who in a paper entitled "Oil price uncertainty in a small open economy" show that if a country is open to international financial markets, oil price volatility shocks would increase precautionary savings and thus, increasing household savings. The effect of this would depend on where the country can invest those savings, namely in international bonds or not. Therefore, if there is low substitutability between oil and other factors of production, it would lead to an increase in precautionary savings and real GDP. However, if households have access to international bonds this result can be overturned since they are not only investing in physical capital. This finding is consistent with an early exposition on general inflation uncertainty and savings behaviour by Wachtel (1977), who noted that savings behaviour is a function of both expected level of real income and the uncertainty surrounding those expectations, such that 
uncertainty of real income expectations which rises with inflation induces an increase in precautionary savings.

The current study analyses the relationship between oil price volatility and savings in South Africa. This builds on the research that has already been done on oil prices in South Africa (e.g. Nkomo 2006a, b; Swanepoel, 2006; Gupta and Modise, 2013; Chisadza et al., 2013, Aye et al. 2014 amongst others). However, none of these studies analysed the effect of oil price volatility except Aye et al. 2014. Aye et al. 2014 focused on manufacturing production while the current study focuses on savings. A GARCH-in-mean VAR was used to account for the volatility of oil prices and heteroskedasticity. This model also has the ability to separate the responses of savings to positive and negative shocks of oil price using impulse response functions.

\section{Empirical Model}

The empirical model used in this study was initially developed by Elder $(1995,2004)$ and used in Elder and Serletis (2010) as well as Aye et al. (2014). It is a bivariate quarterly model in real savings growth and the real oil price growth. The model is based on a structural VAR with modifications for conditional heteroskedasticity in the parametric form of the bivariate GARCH-in-mean. The main assumption is that the dynamics of the structural system can be summarized by a linear function of the variables of interest, and a term related to the conditional variance which is given as:

$$
\mathbf{B} y_{t}=\mathbf{C}+\boldsymbol{\Gamma}_{1} \mathbf{y}_{t-1}+\boldsymbol{\Gamma}_{2} \mathbf{y}_{t-2}+\ldots+\boldsymbol{\Gamma}_{p} \mathbf{y}_{t-p}+\boldsymbol{\Lambda}(\mathbf{L}) \sqrt{\mathbf{H}_{t}}+\varepsilon_{t}
$$


where $\operatorname{dim}(\mathbf{B})=\operatorname{Dim}\left(\Gamma_{\mathrm{i}}\right)$ are $\mathrm{p} \times \mathrm{p}$ matrices, $\sqrt{\mathbf{H}_{\mathrm{t}}}$ is a diagonal and $\boldsymbol{\Lambda}(\mathbf{L})$ is a matrix polynomial in the lag operator. $\mathbf{y}_{\mathrm{t}}$ is a vector containing real oil price and real savings growth rates, $\varepsilon_{\mathrm{t}} \| \Pi_{\mathrm{t}-1} \sim$ iid $\left(\mathbf{0}, \mathbf{H}_{\mathrm{t}}\right)$ represents uncorrelated structural disturbances in the system where $\Pi_{t-1}$ is the available information set at time $\mathrm{t}-1$.

The above specification allows the matrix of conditional standard deviations $\left(\sqrt{\mathbf{H}_{\mathrm{t}}}\right)$ to affect the conditional mean. To test whether oil price volatility affects savings, a test of restrictions on the elements of $\boldsymbol{\Lambda}(\mathbf{L})$ that relate the conditional standard deviation of savings, given by the appropriate element of $\sqrt{\mathbf{H}_{t}}$, to the conditional mean of $\mathbf{y}_{\mathrm{t}}$ is performed. If oil price volatility has adversely affected savings, then one would expect to find a negative and statistically significant coefficient on the conditional standard deviation of oil in the savings equation.

The conditional variance $\mathbf{H}_{\mathrm{t}}$ is modelled as bivariate GARCH of which a general version is represented in Engle and Kroner (1995) as:

$\mathbf{h}_{t}=\mathbf{C}_{v}+\sum_{j=1}^{J} \mathbf{F}_{i} \operatorname{vec}\left(\varepsilon_{t-j} \varepsilon_{t-j}^{\prime}\right)+\sum_{i=1}^{I} \mathbf{G}_{i} \mathbf{h}_{t-i}$

$\varepsilon_{t} \sim \sqrt{\mathbf{H}_{t}} \mathbf{z}_{t} ; \mathbf{z}_{t} \sim \operatorname{iidN}(0, \mathbf{I})$, where $\mathbf{C}_{v}$ is $\mathrm{N}^{2} \times 1$ matrix, $\mathbf{F}$ and $\mathbf{G}$ are $\mathrm{N}^{2} \times \mathrm{N}^{2}$ matrices and $\mathbf{h}_{t}=\operatorname{vec}\left(\mathbf{H}_{t}\right)$. This condition does not however guarantee that $\mathbf{H}_{t}$ is positive definite.

Imposing a common identifying assumption in structural VARs simplifies the variance function written in terms of the structural disturbances (Elder, 2004). In other words, given a zero contemporaneous correlation of structural disturbances, the conditional variance matrix $\mathbf{H}_{t}$ is then diagonal, reducing the necessary number of variance function parameters 
substantially. By re-dimensioning the variance function parameter matrices $\mathbf{C}_{v} \mathbf{F}$ and $\mathbf{G}$, the variance function reduces to

$\operatorname{diag}\left(\mathbf{H}_{t}\right)=\mathbf{C}_{v}+\sum_{j=1}^{J} \mathbf{F}_{i} \operatorname{diag}\left(\varepsilon_{t-j} \varepsilon_{t-j}^{\prime}\right)+\sum_{i=1}^{I} \mathbf{G}_{i} \operatorname{diag}\left(\mathbf{H}_{t-i}\right)$

where diag is the operator that extracts the diagonal from a square matrix. The second and third terms on the RHS of equation (3) represents the ARCH and GARCH, terms respectively. Imposing an additional restriction that the conditional variance of $y_{i, t}$ depends only on its own past squared errors and its own conditional variances, the parameter matrices $\mathbf{F}_{j}$ and $\mathbf{G}_{i}$ are also diagonal. The variance function given by equation (3) is estimated with $J=I=1$, which is the specification for a GARCH $(1,1)$-in-mean VAR model.

The bivariate GARCH-in-mean VAR model is therefore given by equations (1) and (3) which are simultaneously estimated by full information maximum likelihood (FIML), a procedure which avoids Pagan's (1984) generated regressor problem related to estimating the variance function parameters separately from the conditional mean parameters. The procedure is to maximize the log likelihood with respect to the structural parameters $\mathbf{B}, \mathbf{C}, \boldsymbol{\Gamma}_{1}, \boldsymbol{\Gamma}_{2}, \ldots, \boldsymbol{\Gamma}_{p}, \boldsymbol{\Lambda}, \mathbf{F}$ and $\mathbf{G}$, where

$l_{t}=-(N / 2) \ln (2 \pi)+1 / 2 \ln |\mathbf{B}|^{2}-1 / 2 \ln |\mathbf{H}|_{t}-1 / 2\left(\varepsilon_{t}^{\prime} H_{t}^{-1} \varepsilon_{t}\right)$

Consistent with Elder and Serletis (2010), the pre-sample values of the conditional variances matrix $\mathbf{H}_{0}$ are set to their unconditional expectation and condition on the pre-sample values $\mathbf{y}_{0,} \mathbf{y}_{t-1, \ldots,} \mathbf{y}_{t-p+1}$. The following restrictions are imposed to ensure a positive definite and covariance stationary $\mathbf{H}_{t}$ and $\varepsilon_{t}$ respectively: $\mathbf{C}_{v}$ is element wise-positive, $\mathbf{F}$ and $\mathbf{G}$ are 
element-wise non-negative, and the Eigen-values of $(\mathbf{F}+\mathbf{G})$ are less than one in modulus. Under the assumption that the standard regularity conditions hold, FIML produces asymptotically normal and efficient estimates, with the asymptotic covariance given by the inverse of the Fisher's information matrix. By imposing the usual identifying procedure in VARs, one can estimate free parameters in $\mathbf{B}$ subject to a rank condition. This means that in a bivariate VAR, one can estimate one free parameter in $\mathbf{B}$. To do so, this study follows Edelstein and Kilian (2007) and Elder and Serletis (2010) and allow the savings to respond to the change in the oil price.

An important tool in VAR analysis is the impulse response function which simulates the effects of a shock to one variable in the system on the conditional forecast of another variable. The impulse responses for the GARCH-in-mean VAR are calculated following Elder (2003). The confidence (error) bands are constructed using the Monte Carlo method described in Hamilton (1994, p.337). This implies that the impulse responses are simulated from the maximum likelihood estimates (MLEs) of the parameters of the model. Then based on parameter values drawn randomly from the sampling distribution of the MLEs, confidence intervals are generated by simulating 1000 impulse responses. It should be noted that the Fisher's information matrix is used to obtain the covariance matrix of the MLEs.

\section{Data and Empirical Results}

Brent crude oil which is seen as a "sour" oil that needs more processing to remove impurities has now become more expensive than the "sweet" crude oil that is extracted in places such as Texas. This "sweet" crude oil involves less processing and is preferred over Brent crude oil because it has multiple uses (Dutram, 2011). This paper uses West Texas Institute oil price 
from the U.S. Energy Information Administration. Gross savings data was obtained from the South African Reserve Bank. The data used covers the period of the first quarter of 1960 until the first quarter of 2014. Monthly oil prices were converted to quarterly oil prices which were used together with quarterly data of gross savings. Both series were also converted from nominal to real data by dividing by the US CPI and South African CPI respectively. The US CPI and South African CPI were obtained from Federal Reserve Bank of St. Louis and International Financial Statistics (IFS) respectively. The real oil price was further converted from US Dollar to South African Rand using quarterly Rand-US Dollar exchange rate data from IFS. Lastly both series were logged and the first difference was taken to correct for nonstationarity as indicated by the unit root tests discussed below. This obtained the real growth rates of oil prices and savings in Rands. The figures relating to both levels and growth rates of oil price and savings are reported in Figures 1 to 4 . Oil price volatility refers to the degree to which oil prices fluctuate over time. It is not directly observable and hence has to be measured from change in oil prices. The measure of oil price volatility in this study is the conditional standard deviation of the one-step-ahead forecast error of change in oil price. This measure is consistent with Elder and Serletis (2010).

The Dickey Fuller (1981) and Phillips and Perron (1988) unit root tests were used to test for stationarity of the two series. Table 1 indicates that the series is integrated of order 1 [that is I(1)] due to the fact that the first difference of both series is significant for stationarity. Therefore, the logged first difference of both series was used in the model. This reduced the sample by one lag implying that the effective sample is from 1960Q2 to 2014Q1. Figures 1 and 3 graphically confirm that the data is non-stationary. However, figures 2 and 4 confirm stationarity after taking the logged first difference (growth rates) of both series. 
The GARCH-in-mean VAR model was estimated using 4 lags, as suggested by the Akaike Information Criteria (AIC). The Schwarz Information Criteria (SIC) offers a penalty for any additional parameters necessary for estimating the GARCH model and thus an improvement in SIC suggests strong evidence in favour of the model employed (Aye et al., 2014). The SIC value of the homoscedastic VAR is 3431 and is larger than the SIC value of the GARCH-inmean of 3397, as shown in Table 2. This implies that the model holds the essential features of the data.

Table 3 shows the coefficient estimates for the variance function of the GARCH-in-mean VAR and the variables of the VAR. The results support the use of the model specification. Quarterly analysis confirms that the volatility of real oil prices is persistent due to all the coefficients being significant. The coefficient of 0 confirms the assumption of the nonnegativity requirement.

The results show that oil price volatility has an overall negative and significant effect on savings. This is proven by using the coefficient of the standard deviation of real oil price changes in the savings growth equation. The coefficient is -0.0166 with a p-value of 0.00 , which implies that real oil price uncertainty will have a significant and negative effect on savings, although rather small.

Figure 5 includes the impulse response functions of an oil price shock, based on the standard deviation of real oil prices, on the response of savings using the maximum likelihood estimates of the parameters. The impulse responses (solid lines) with the one-standard deviation error band (dashed lines) are shown in the graphs. Positive and negative oil price shocks were used to test for symmetric responses. 
Symmetric responses on savings are confirmed in Figure 5 by direction and magnitude. A positive oil shock creates an immediate reduction in savings growth in the first quarter. Thereafter, increasing savings growth in the second quarter and decreasing it again in the third quarter. This rather volatile response continues until 7 quarters and the shock stabilises around the $11^{\text {th }}$ quarter. A negative oil price shock has the complete opposite effect on savings growth, causing an initial increase in savings growth in the first quarter. This is followed by decreased and increased savings growth in the second and third quarters. Growth in savings is then decreased for the next 3 quarters and stabilises around the $11^{\text {th }}$ quarter.

The results indicate that increases in uncertainty about oil prices on savings may reduce the willingness of business firms to commit their resources to irreversible investments and consumers to spend on illiquid durables. This will affect labour and capital productivity (especially if these are immobile or costly to move) and consequently overall savings in the economy negatively. This results contrasts the findings by Baskaya et al. (2013) who found a positive relationship but is in line with the theoretical exposition that savings may decline if households perceive that increases in oil price is transitory and hence decides to smoothen consumption by saving less and borrowing. However, since the effect of oil price volatility on savings is quantitatively small (about $2 \%$ ), one can assume that there are other factors that have more impact on savings. These factors could include interest rates, inflation and unemployment. Again these factors are equally affected by oil prices. The South African Reserve Bank (SARB) needs to work together with the government to keep inflation in the target range of between $3 \%$ and $6 \%$. Wages also need to increase with inflation. There are not enough savings because people do not earn enough to be able to set money aside every month, or they do not have a job at all. Policies need to allow for the reduced savings that the country has been experiencing over the last few years. If wages are increased and workers are offered incentives, they will be more productive and this will in turn increase the growth in 
the country. This will lead to more stable indicators such as inflation and interest rates which would hopefully encourage savings. Reducing consumption could increase the flow of money towards savings. Various instruments can be used in both monetary and fiscal policies in order to grow savings, however, interest rates remains as the leading instrument to adjust savings. Overall, policies that attempt to reduce the volatility in oil prices will help to spur investors especially in the energy-intensive sectors to increase their level of investment and consumers to increase their purchases of durable goods. These would in turn increase investment and savings in South Africa. 


\section{Conclusion}

This paper examines the impact of real oil price uncertainty on real savings in South Africa. Using a GARCH-in-mean VAR model accounted for the volatility/uncertainty by using the standard deviation of the one-step ahead forecast error of the growth rate of real oil prices. Data was used from the second quarter of 1960 until the first quarter of 2014. The result of the model shows us a slight negative relationship between oil price volatility and savings. Impulse response functions confirm the initial reduction of savings in the first quarter to a positive oil price shock, while an initial increase in savings in the first quarter can be observed after a negative oil price shock. These responses are also symmetric in direction and magnitude with regards to positive and negative oil price shocks. The small negative coefficient of oil price volatility on saving indicates that there must be other factors that contribute towards the recent low levels of savings. These could be inflation, interest rates and unemployment. However, in any case all of these could be linked to oil price increases given the different channels through which oil prices can affect the economy. The SARB needs to work together with government in order to develop policies that will account for the persistent low saving rates but should also help to encourage savings. Various instruments can be used in both monetary and fiscal policies in order to grow savings, however, interest rates remains as the leading instrument to adjust savings. Wages could also be increased to be enough to meet one's expenses, manage inflation and be able to save. A reduction in consumption may lead to money flowing towards savings. If oil prices amongst other factors are handled better by the SARB and government, stable interest rates, borrowing of capital by foreigners, as well as savings would improve the overall investment and growth of the country. 


\section{References}

Al-Khouri, R. and Dhade, A. (2014). The Role of Savings in Reducing the Effect of Oil Price Volatility for Sustainable Economic Growth in Oil Based Economies: The Case of GCC Countries. International Journal of Economics and Finance, 6(4).

Aye, G. C., Dadam, V., Gupta, R. and Mamba, B. (2014). Oil price uncertainty and manufacturing production. Energy Economics, Volume 43, pp. 41-47.

Basher, S.A. and Sadorsky, P. (2006). Oil price risk and emerging stock markets. Global Finance Journal , 17, 224-251.

Başkaya, Y.S., Hülagü, T. and Küçük, H. (2013). Oil price uncertainty in a small open economy. Central Bank of the Republic of Turkey 2013, Working paper no: 13/09.

Chisadza, C., Dlamini, J., Gupta, R. and Modise, M.P. (2013). The Impact of oil shocks on the South African economy. Department of economics, University of Pretoria, working paper, 2013-11.

Degiannakis, S., Angelidis, T. and Filis, G. (2013). Oil price shocks and volatility do predict stock market regimes. Bank of Greece, Economic Research Department - Special Studies Division, Working paper, 170.

Dickey, D.A. and Fuller, W.A. (1981). Distribution of the estimators for autoregressive time series with a unit root. Econometrica 49, 1057-1072.

Dutram, E. (2011). Crude Oil Guide: Brent Vs. WTI, What's The Difference?. [Online] Available at: http://commodityhq.com/2011/crude-oil-guide-brent-vs-wti-whats-thedifference/

[Accessed September 2014]. 
Edelstein, P. and Kilian, L., 2007. The response of business fixed investment to changes in energy prices: a test of some hypothesis about the transmission of energy price shocks. B.E. J. Macroecon. 7, 35.

Elder, J. and Serletis, A. (2010). Oil price uncertainty. Journal of Money Credit and Banking, 42(6), 1137-1159.

Elder, J. (1995). Macroeconomic and financial effects of monetary policy and monetary policy uncertainty. Ph.D. Dissertation University of Virginia.

Elder, J. (2003). An impulse response function for a vector autoregression with multivariate GARCH-in-Mean. Econ. Lett. 79, 21-26.

Elder, J. (2004). Another perspective on the effects of inflation volatility. J. Money Credit Bank. 36, 911-928.

Engle, R.F. and Kroner, K.F. (1995). Multivariate simultaneous generalized ARCH. Econ. Theory $11,122-150$.

Gupta R. and Modise, M.P. (2013). Does the source of oil price shocks matter for South African stock returns? A structural VAR approach. Energy Economics, 40(1), 825-831.

Hamilton, J.D. (1994). Time Series Analysis. Princeton University Press, Princeton, NJ. Lescaroux, F. and Mignon, V. (2008). On the influence of oil prices on economic activity and other macroeconomic and financial variables. OPEC Energy Review, 32(4), 343-380.

Lin, B., Wesseh Jr, P.K. and Appiah, M.O. (2014). Oil price fluctuation, volatility spillover and the Ghanaian equity market: Implication for portfolio management and hedging effectiveness. Energy Economics 42, 172-182. 
Nkomo, J. (2006a). The impact of higher oil prices on Southern African countries. Journal of Energy South Africa, 17(1), 10-17.

Nkomo, J. (2006b). Crude oil price movements and their impact on South Africa. Journal of Energy South Africa, 17(4), 25-31.

Olson, E., Vivian, A.J. and Wohar, M.E. (2014) The relationship between energy and equity markets: Evidence from volatility impulse response functions. Energy Economics 43, 297_305.

Omojolaibi, J.A. and Egwaikhid, F.O. (2014). Oil price volatility, fiscal policy and economic growth: a panel vector autoregressive (PVAR) analysis of some selected oil-exporting African countries. OPEC Energy Review, 38(2), 127-148.

Pagan, A. (1984). Econometric issues in the analysis of regressions with generated regressors. Int. Econ. Rev. 25, 221-247.

Papapetrou, E. (2001). Oil price shocks, stock markets, economic activity and employment in Greece. Energy Economics, 23, 511-532.

Phillips, P.C. and Perron, P. (1988). Testing for a unit root in time series regression. Biometrika 75, 335-346.

Sadorsky, P. (1999). Oil price shocks and stock market activity. Energy Economics, 21, 449-469.

Sadorsky, P. (2004). Stock markets and energy prices. Encyclopedia of Energy, 5, 707-717.

Solow, R. M. (1956). A Contribution to the Theory of Economic Growth. The Quarterly Journal of Economics, 70(1), pp. 65-94. 
Swanepoel, J.A. (2006). The impact of external shocks on South African inflation at different price stages. Journal for Studies in Economics and Econometrics, 30(1), 1-22.

Trading Economics (2014). South Africa Households Savings. [Online] Available at: http://www.tradingeconomics.com/south-africa/personal-savings [Accessed October 2014].

U.S. Energy Information Administration (2014). Petroleum \& other liquids. [Online] Available at: http://www.eia.gov/dnav/pet/hist/LeafHandler.ashx?n=PET\&s=RWTC\&f=M [Accessed October 2014].

Wachtel, P. (1977) Inflation, uncertainty, and saving behavior. In Zarnowitz, V. and Moore, G.H. (editors), Explorations in Economic Research, 4(4), chapter 2, 88-108. NBER. http://www.nber.org/chapters/c9102. 
Table 1 - Unit Root Tests

\begin{tabular}{|c|c|c|c|c|}
\hline \multirow[t]{3}{*}{ Variables } & \multicolumn{4}{|l|}{ Level } \\
\hline & \multicolumn{2}{|l|}{ Intercept } & \multicolumn{2}{|c|}{ Trend and intercept } \\
\hline & ADF & $\mathbf{P P}$ & ADF & $\mathbf{P P}$ \\
\hline Real Oil Price & 3.037 & 4.131 & 0.983 & 0.854 \\
\hline \multirow[t]{4}{*}{ Real Savings } & -1.127 & -2.438 & -2.522 & $-6.694 * * *$ \\
\hline & \multicolumn{4}{|c|}{ First Difference } \\
\hline & \multicolumn{2}{|l|}{ Intercept } & \multicolumn{2}{|c|}{ Trend and intercept } \\
\hline & ADF & $\mathbf{P P}$ & ADF & $\mathbf{P P}$ \\
\hline Real Oil Price & $-11.923 * * *$ & $-10.644 * * *$ & $-9.828 * * *$ & $-11.820 * * *$ \\
\hline Real Savings & $-16.733 * * *$ & $-25.286 * * *$ & $-16.693 * * *$ & $-25.218 * * *$ \\
\hline
\end{tabular}

Note: $* * *$ denotes significance at $1 \%$ level

$\underline{\text { Table } 2 \text { - Model specification tests (Schwarz Information Criteria) }}$

\begin{tabular}{|c|c|c|}
\hline Bivariate model & SIC VAR & SIC GARCH-in-mean \\
\hline Real savings \& real oil & 3431 & 3397 \\
prices & & \\
\hline
\end{tabular}

Table 3 - Coefficient estimates for the variance function of the GARCH-in-mean VAR

\begin{tabular}{|c|c|c|c|c|}
\hline & $\begin{array}{c}\text { Conditional } \\
\text { Variance }\end{array}$ & Constant & $\varepsilon_{j}(\boldsymbol{t}-\mathbf{1})^{\mathbf{2}}$ & $\boldsymbol{H}_{\boldsymbol{j}}(\boldsymbol{t}-\mathbf{1})$ \\
\hline Oil Equation & $\boldsymbol{H}_{\text {oil }}(\boldsymbol{t})$ & $51.75^{* * *}$ & $0.92^{* * * *}$ & 0.00 \\
\hline
\end{tabular}




\begin{tabular}{|c|c|c|c|c|}
\hline & & $(7.24)$ & $(9.06)$ & \\
\hline Savings & $\boldsymbol{H}_{\text {sav }}(\boldsymbol{t})$ & $5.70 * * *$ & $0.10 * * *$ & $0.87 * *$ \\
Equation & & $(28.09)$ & $(8.08)$ & $(60.15)$ \\
\hline
\end{tabular}

Note: $* * *$ denotes significance at $1 \%$ level 
Figure 1

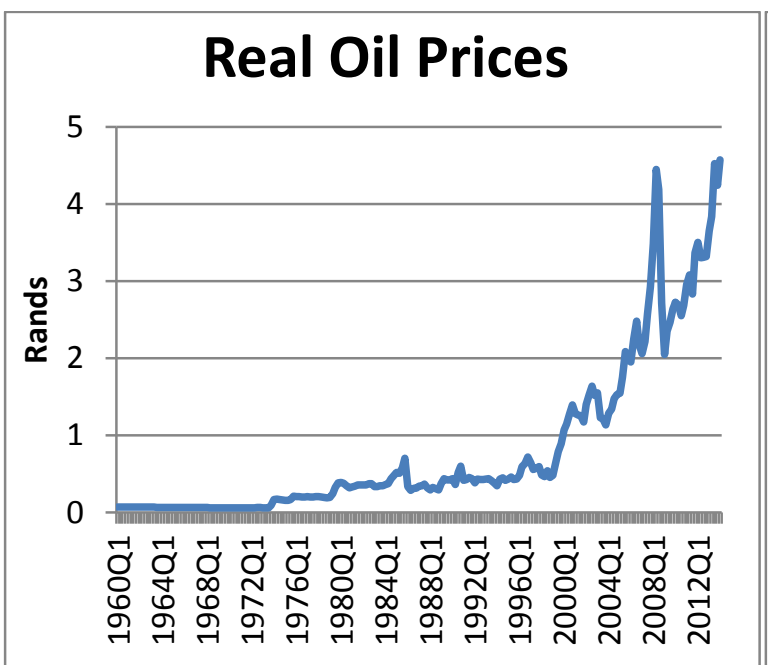

Figure 2

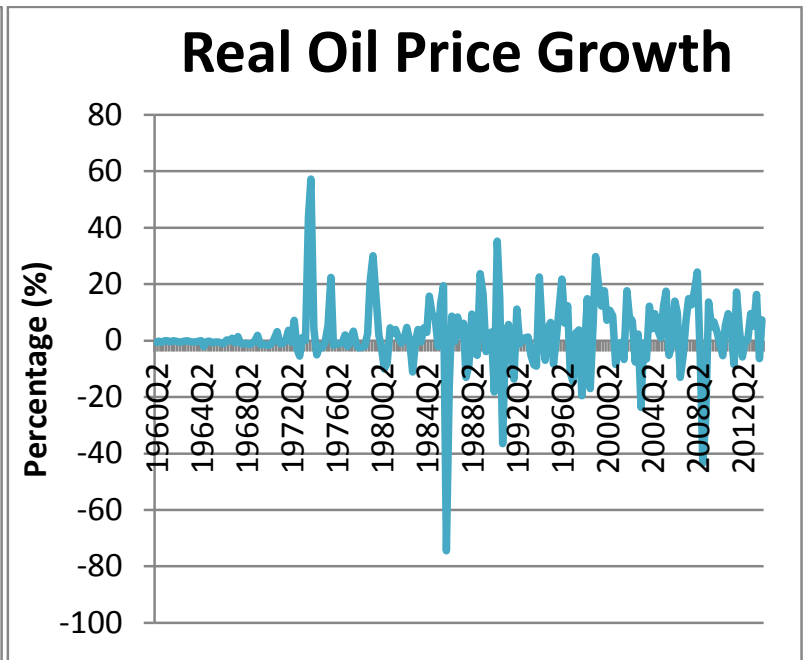

$\underline{\text { Figure } 3}$

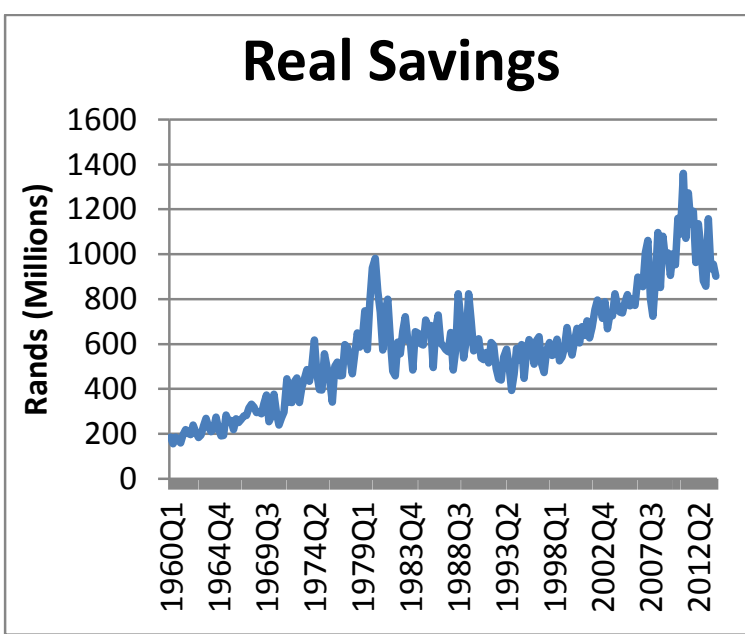

Figure 4

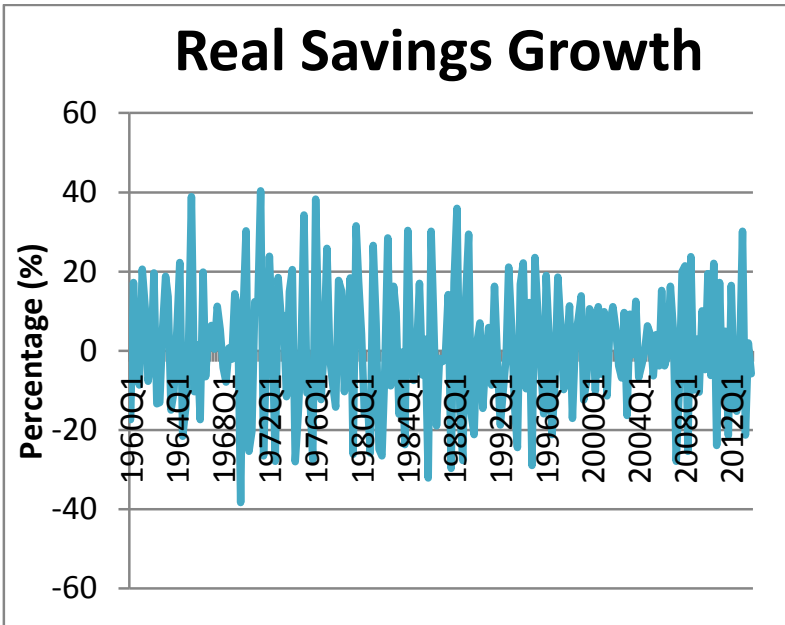


Figure 5 - Impulse Response Functions
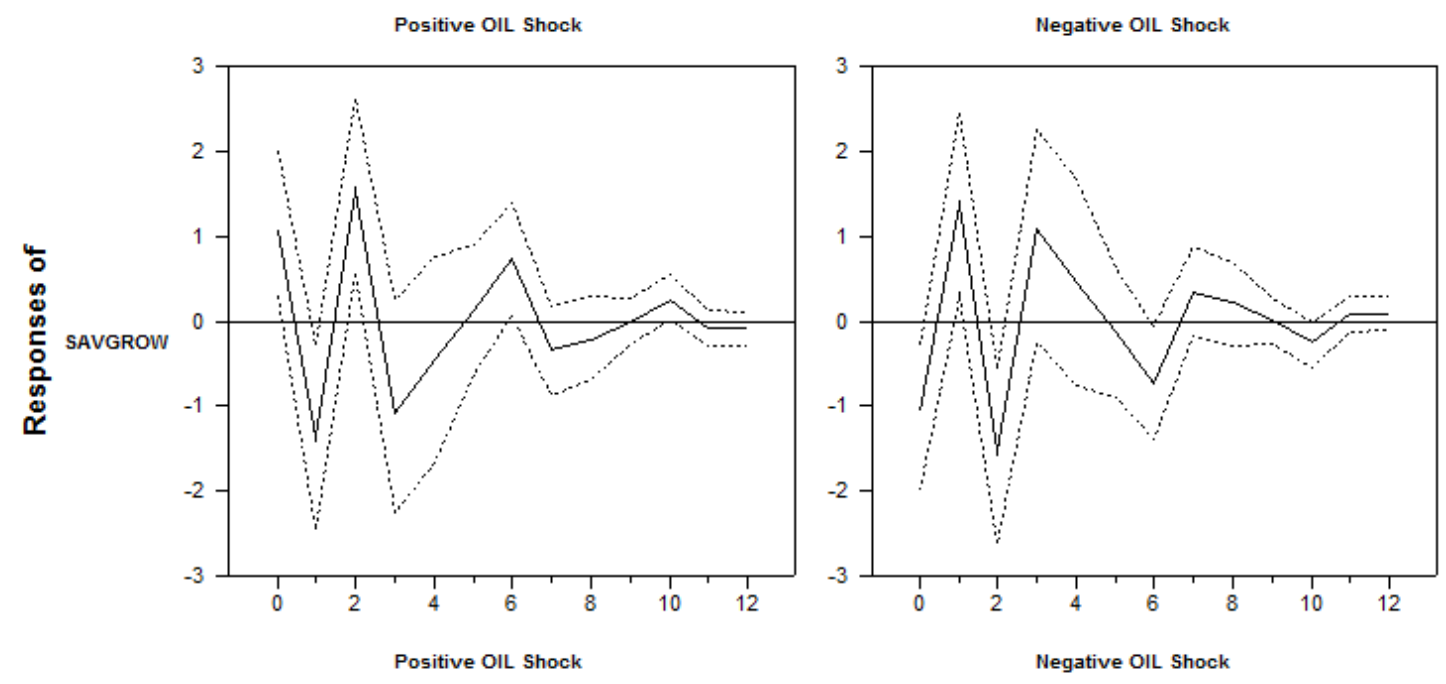